University of Nebraska - Lincoln

DigitalCommons@University of Nebraska - Lincoln

Biological Systems Engineering: Papers and

Publications

Biological Systems Engineering

$11-2009$

\title{
Extraction and characterization of natural cellulose fibers from common milkweed stems
}

Narendra Reddy

University of Nebraska-Lincoln, nreddy3@unl.edu

Yiqi Yang

University of Nebraska-Lincoln, yyang2@unl.edu

Follow this and additional works at: https://digitalcommons.unl.edu/biosysengfacpub

Part of the Biological Engineering Commons

Reddy, Narendra and Yang, Yiqi, "Extraction and characterization of natural cellulose fibers from common milkweed stems" (2009). Biological Systems Engineering: Papers and Publications. 161.

https://digitalcommons.unl.edu/biosysengfacpub/161

This Article is brought to you for free and open access by the Biological Systems Engineering at DigitalCommons@University of Nebraska - Lincoln. It has been accepted for inclusion in Biological Systems Engineering: Papers and Publications by an authorized administrator of DigitalCommons@University of Nebraska Lincoln. 


\title{
Extraction and characterization of natural cellulose fibers from common milkweed stems
}

\author{
Narendra Reddy ' and Yiqi Yang I, 2, 3 \\ ' Department of Textiles, Clothing \& Design, University of Nebraska-Lincoln \\ 2 Department of Biological Systems Engineering, University of Nebraska-Lincoln \\ ${ }^{3}$ Nebraska Center for Materials and Nanoscience, University of Nebraska-Lincoln
}

Corresponding author - Yiqi Yang, Department of Textiles, Clothing \& Design, 234 HECO Building, University of Nebraska-Lincoln East Campus, Lincoln, Nebraska 68583-0802; e-mail: yyang2@unl.edu

\begin{abstract}
Natural cellulose fibers with cellulose content, strength, and elongation higher than that of milkweed floss and between that of cotton and linen have been obtained from the stems of common milkweed plants. Although milkweed floss is a unique natural cellulose fiber with low density, the short length and low elongation make milkweed floss unsuitable as a textile fiber. The possibility of using the stems of milkweed plant as a source for natural cellulose fibers was explored in this research. Natural cellulose fibers extracted from milkweed stems have been characterized for their composition, structure, and properties. Fibers obtained from milkweed stems have about $75 \%$ cellulose, higher than the cellulose in milkweed floss but lower than that in cotton and linen. Milkweed stem fibers have low \% crystallinity when compared with cotton and linen but the strength of the fibers is similar to cotton and elongation is higher than that of linen fibers.
\end{abstract}

\section{Introduction}

Milkweed is a valuable plant that is easy to grow in dry and arid climates, requires minimum water, and can be harvested for floss twice every year [1,2]. The parts of the milkweed plants are used for various applications. Fibers (floss) produced from the plant have low density $(0.9 \mathrm{~g} / \mathrm{cm} 3)$ unlike any other natural cellulose fiber and attempts have been made to use the floss as a filling material in jackets and for nonwovens [3-5]. However, the short lengths and low elongation limit the use of floss as a natural cellulose fiber for textile and other applications [6, 7]. Common natural cellulose fibers in current use have length greater than $2 \mathrm{~cm}$ and elongation of at least $2 \%$. Because of its short length, milkweed floss has been blended with cotton and processed to de- velop yarns and fabrics [8,9]. A variant of the common milkweed, the giant milkweed (Calotropis persica) has been used as reinforcement with polypropylene binders in extruded composites [2]. Seeds from the plant have been evaluated as a potential source for oil and biodiesel [10]. The stem of the milkweed plant has also been used to extract oil and natural rubber [11, 12]. The potential of using milkweed plants as a source of pulp for paper was also studied [13]. Currently, milkweed plants are being commercially processed for floss used in comforters and other parts of the plants are also being sold. However, there are no reports available on the use of the milkweed stems as sources for high quality natural cellulose fibers.

Stems of plants such as jute, flax, ramie, and hemp have traditionally been used to obtain natural cellulose fibers. These plants are almost exclusively grown as fiber crops and there is a growing concern on the future availability and price of the fibers from these crops due to the limitations of land, water, and energy needed to grow these crops. Therefore, attempts are being made to develop alternative sources for natural cellulose fibers. Byproducts of agricultural crops are being considered as inexpensive, abundant, annually renewable, and sustainable sources for natural cellulose fibers. The byproducts of major food crops including cornhusks, cornstalks, rice and wheat straw and sorghum stalk and leaves, pineapple leaves and sugarcane stalks have all been studied as potential fiber sources [14-23]. It has been shown that fibers obtained from these alternative sources have properties similar to or better than the properties of cotton and linen. Fibers obtained from 
cornhusks have been processed into yarns and also used to develop composites with properties similar to that of jute composites [24, 25].

Finding alternative sources for the natural and synthetic fibers in current use is essential to have adequate supply of fibers at affordable prices in future. The increasing cost and decreasing availability of petroleum resources and limitations in the availability of land, water, and other resources required to grow natural fibers could restrict the availability and/or increase the price of common fibers making them unaffordable for commodity applications. In addition, higher income from biofuel crops such as corn is leading to the decline in the production of natural fibers, especially cotton. Therefore, efforts to find alternative fiber sources, especially from the inexpensive, abundantly available, and renewable lignocellulosic byproducts are highly valuable.

In this research, the potential of extracting natural cellulose fibers from the stems of milkweed plants has been studied. Fibers have been extracted from milkweed stems and the composition, structure, and properties of the fibers has been studied in comparison to properties of milkweed floss, cotton, and linen. The data for milkweed floss, cotton, and linen are from literature and a range of data has been reported to include the values reported by various sources.

\section{Experimental}

\section{Materials}

Milkweed stems were supplied by Natural Fibers Corporation, Ogallala, Nebraska. The outer skin of the bark was peeled from the stems by hand and used for fiber extraction. The inner bark was very tough and not suitable for extracting fibers. All chemicals used in this study were reagent grade obtained from VWR International, Bristol, CT.

\section{Fiber Extraction}

We studied several conditions to extract fibers from the milkweed stems based on our experiences in obtaining fibers from various agricultural byproducts. We observed that the milkweed stems were sensitive to extraction conditions. Strong alkali conditions and/or heating of the stalks at temperatures above $80^{\circ} \mathrm{C}$ resulted in the disintegration of the bark into small fibers, not suitable for high value fibrous applications. After several trials, the most optimum conditions of fiber extraction were developed based on the yield, length, and strength of fibers obtained. Under the optimum conditions, the peeled bark was dipped in $0.5 \mathrm{~N}$ sodium hydroxide solution with a solution to bark ratio of 10:1 at room temperature overnight. The solution was then heated to $80^{\circ} \mathrm{C}$ for $30 \mathrm{~min}$. The extracted components were then drained and the fibers formed were thoroughly washed first in warm and later in cold water, neutralized in dilute acetic acid solution to remove any remaining alkali, and air dried.

Single cells or "ultimates" were obtained from the fibers by maceration. Single cells are the smallest morphological units in fibers and measure a few millimeters in length. The single cells are too small for use in high value fibrous applications but are used in the paper and pulp industry and commonly referred to as "ultimates or fibers." In this manuscript, fibers refer to a bundle of single cells held together by lignin and other binding materials.

Maceration of the milkweed stem fibers to obtain the single cells was done using equal amounts of $10 \%(\mathrm{w} /$ $\mathrm{w})$ nitric acid and 10\% (w/w) chromic acid solutions. Fibers were dipped in equal amounts of the solutions for about $24 \mathrm{~h}$ after initiating the reaction by heating the solution at $60^{\circ} \mathrm{C}$ for $5 \mathrm{~min}$ [26]. The treated fibers were thoroughly washed in water and dried using ethanol.

\section{Fiber Composition}

The composition of the milkweed stem fibers in terms of the $\%$ cellulose, lignin, and ash content was determined using standard test methods. Cellulose in the fibers was determined as the Acid Detergent Fiber (ADF) according to AOAC method 973.18 [27]. Lignin in the fibers was determined as Klason lignin according to ASTM method D1106-96 and ASTM method E1755-01 was used to determine the ash content in the fibers [28]. Three replications were done for determining each component and the average and \pm one standard deviation is reported.

\section{Physical Structure}

The \% crystallinity and shape and position of the cellulose peaks in the milkweed stem fibers were observed using an X-ray diffractometer. Raw cotton fibers were also used to obtain the diffraction patterns for comparison with the milkweed stem fibers. A Rigaku D-max/ $\mathrm{B} \Theta / 2 \Theta$ X-Ray diffractometer (Rigaku Americas, Woodlands, TX) with Bragg-Brentano parafocusing geometry, a diffracted beam monochromator, and a copper target X-ray tube set to $40 \mathrm{kV}$ and $30 \mathrm{~mA}$ was used to obtain the diffraction patterns and determine the $\%$ crystallinity of the cellulose in the fibers. The milkweed stem fibers and cotton were ground in a Wiley mill to pass through a $250 \mu \mathrm{m}$ mesh and the powder was pressed into a pellet of about $5 \mathrm{~mm}$ thickness on a hydraulic press operated at 20,000 PSI. Intensity measurements were taken on the pellets for a $2 \theta$ angle varying from 5 to $40^{\circ}$. The $\%$ crystallinity of the milkweed stem fibers was obtained by integrating the area under the crystalline peaks after subtracting the background and air scatter. Further details on calculating the \% crystallinity of cellulose have been reported earlier [29]. 


\section{Morphological Studies}

The morphology of the untreated milkweed stems, fibers obtained from the stems, and the single cells obtained from the fibers were observed using a Hitachi S3000N model variable pressure Scanning Electron Microscope (SEM) (Hitachi High Technologies America, Schaumburg, IL). Samples to be observed under the SEM were mounted on conductive adhesive tape, sputter coated with gold palladium, and observed under the SEM. The widths of the single cells obtained by maceration were measured from the SEM pictures and the lengths of the single cells were measured using a digital microscope. About 100 fibers were measured for the dimensions and the average and \pm one standard deviations are reported.

\section{Tensile Properties}

The milkweed stem fibers were conditioned in a standard testing atmosphere of $21^{\circ} \mathrm{C}$ and $65 \%$ relative humidity for at least $24 \mathrm{~h}$ before performing the tensile tests. The tensile tests were performed on single fibers using an Instron tensile tester (Model 4000, Instron, Norwood, MA) to obtain the breaking tenacity, \% breaking elongation, and Young's modulus of the fibers. A gauge length of $25 \mathrm{~mm}$ and a crosshead speed of $18 \mathrm{~mm} / \mathrm{min}$ were used for the testing. About 50 fibers were tested and the average and \pm one standard deviations are reported.

\section{Moisture Regain}

The moisture regain of the fibers was determined according to ASTM standard method 2654 using standard conditions of $21^{\circ} \mathrm{C}$ and $65 \%$ relative humidity. Three replications were done for the moisture regain measurements and the average and \pm one standard deviations are reported.

\section{Results and Discussion}

\section{Fiber Composition}

Fibers obtained from milkweed stems have much higher cellulose and lower lignin content than the milkweed floss fibers as seen from Table 1. The cellulose content of the milkweed stem fibers is much higher than that in the milkweed floss fibers but lower than that of cotton and

Table I. Comparison of the \% composition of natural cellulose fibers from milkweed stems with milkweed floss, cotton, and linen.

\begin{tabular}{lccc}
\hline Material & Cellulose & Lignin & Ash \\
\hline Milkweed stem fibers & $74.5 \pm 1.8$ & $4.1 \pm 0.8$ & $2.2 \pm 0.03$ \\
Milkweed floss fibers & 55 & 18 & - \\
Cotton & $85-90$ & $0.7-1.6$ & $0.8-2.0$ \\
Linen & $72-82$ & $2-3$ & - \\
\hline
\end{tabular}

Data for milkweed floss, cotton and linen are from references [6, 9, 30]. Errors are \pm one standard deviation.

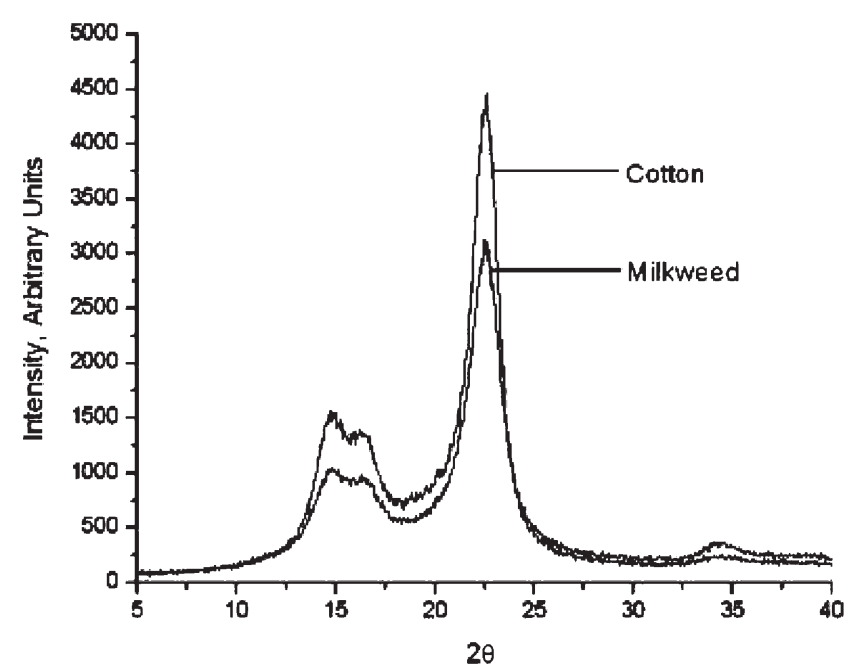

Figure I. Diffractograms of milkweed stem fibers compared to cotton. Cellulose crystals in the milkweed stem fibers show all the peaks seen in cotton.

linen. The milkweed stem fibers also have much lower lignin content when compared with the milkweed floss fibers but higher than the lignin content in cotton and linen. The ash content in the milk weed stem fibers is higher than that in cotton.

As mentioned in the Experimental section, milkweed stems are very sensitive to the alkaline extraction. Relatively mild treatments using alkali alone have produced milkweed stem fibers with high cellulose content but wheat, rice straw, and most other lignocellulosic byproducts need much stronger treatment conditions to extract the fibers but have lower cellulose contents. In addition to the treatment conditions, the chemical composition of the milkweed stems influences the amount of cellulose in the fibers obtained. Most of the lignocellulosic agricultural byproducts have cellulose content of about $40-45 \%$ but the composition of the milkweed stems is not known. Based on the high cellulose content and the relatively weak conditions used to extract the fibers, it is likely that the milkweed stems may have higher cellulose contents than those in the common agricultural byproducts.

\section{Physical Structure}

Fibers obtained from the stems of milkweed plant have $\%$ crystallinity of about $39 \%$, much lower that the \% crystallinity of cotton and linen but similar to the \% crystallinity of cellulose in some of the fibers obtained from the agricultural byproducts such as sorghum [20]. The diffraction patterns of the milkweed stem fibers shows the typical peaks seen in cotton as depicted in Figure 1. The two diffraction peaks at $2 \theta$ values of 13 and $17^{\circ}$ corresponding to the 101 and $101^{-}$planes are distinctly seen, whereas the two peaks combine into one broad peak in milkweed floss fibers and also in most fibers obtained 
Table 2. Single cell dimensions and \% crystallinity of fibers obtained from milkweed stems compared with milkweed floss, cotton, and linen.

\begin{tabular}{|c|c|c|c|c|}
\hline & $\begin{array}{l}\text { Milkweed } \\
\text { stem fibers }\end{array}$ & $\begin{array}{l}\text { Milkweed } \\
\text { floss }\end{array}$ & Cotton & Linen \\
\hline \multicolumn{5}{|c|}{ Single cell dimensions } \\
\hline Length, $\mathrm{mm}$ & $0.9 \pm 0.4$ & 30 & $15-56$ & $4-77$ \\
\hline Width, $\mu \mathrm{m}$ & $13.0 \pm 7.6$ & $10-28$ & $12-25$ & $5-76$ \\
\hline Crystallinity, \% & $39 \pm 5$ & - & $65-70$ & $65-70$ \\
\hline
\end{tabular}

Data for milkweed floss, cotton, and linen are from references [6, 9, 30]. Errors are \pm one standard deviation.

from agricultural byproducts $[9,14-20]$. The higher cellulose and lower lignin and hemicellulose content in the milkweed stem fibers when compared with milkweed floss and other lignocellulosic fibers makes the milkweed stem fibers to have the two distinct peaks [31]. The most prominent cellulose peak corresponding to the 002 diffracting plane at about $22^{\circ}$ is also seen in the milkweed stem fibers.

\section{Morphological Structure}

The single cells in the milkweed stem fibers are much smaller in length and narrower than those in milkweed floss and in cotton and linen as seen from Table 2 but similar to the single cells in most other lignocellulosic agricultural byproducts [14-20]. It should be noted that the milkweed floss and cotton are single cell fibers, whereas all other fibers in Table 2 are multicellular. The length and width of the single cells in the fibers influences the fineness and strength of the fibers obtained. Shorter single cells mean more number of single cells per unit length of the fibers when compared with a fiber composed of longer length single cells. The higher

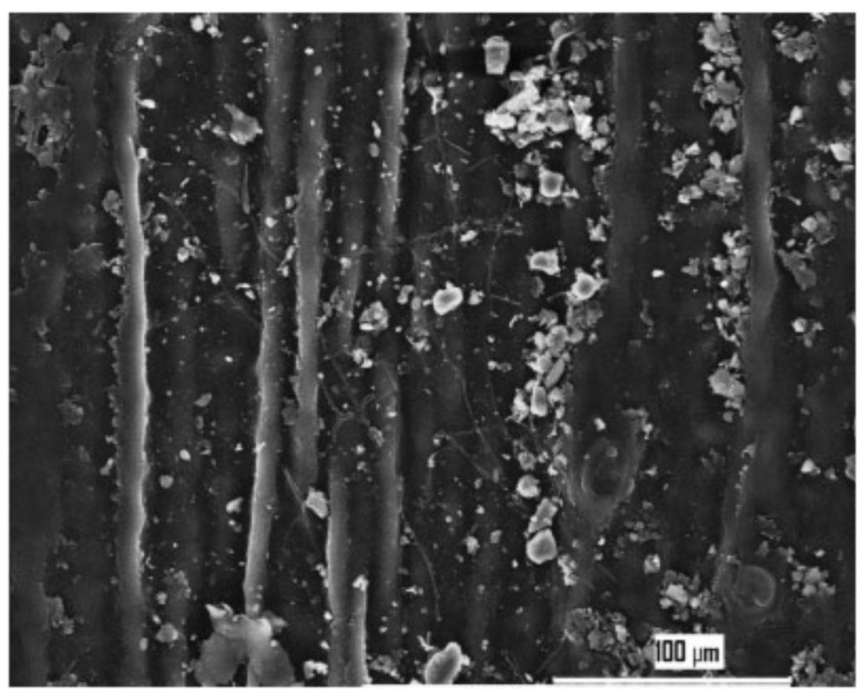

Figure 2. SEM image showing the rough and irregular surface of an untreated milkweed stem composed on non-cellulosic substances.

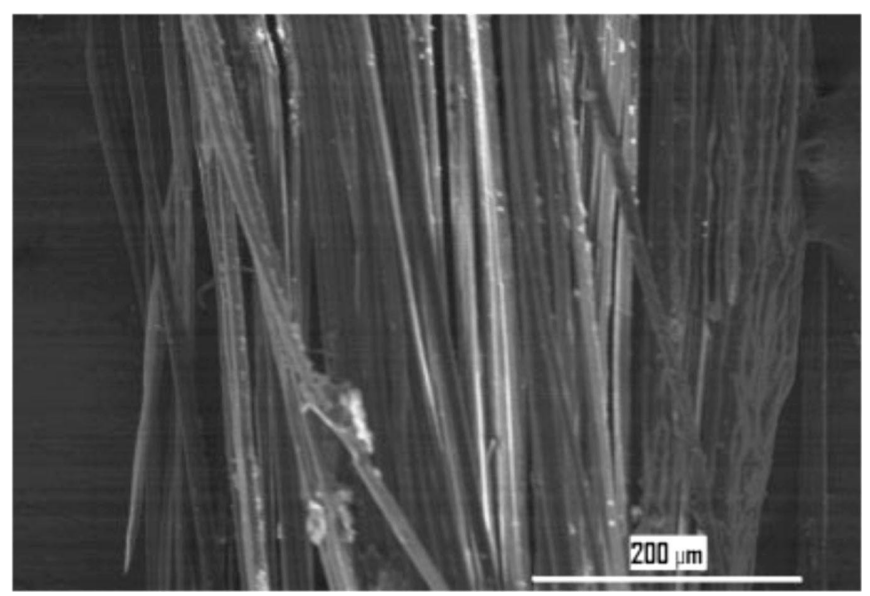

Figure 3. SEM image of the milkweed stem fiber composed of a bundle of single cells. The fiber bundle has a relatively clean and smooth surface compared to the untreated stems.

number of single cells not only means coarser fibers but also higher number of binding spots. The binding spots are the weak places that break easily during tensile testing, and therefore, fibers with shorter single cells will have lower tensile strength when compared with a fiber composed of longer length single cells.

Figures 2-4 show the morphological features of the untreated milkweed stem, fibers, and single cell obtained from the stems, respectively. The untreated stems have a layer of surface deposits mostly composed of lignin, hemicellulose, and other noncellulosic substances that cover the cellulose inside as seen from Figure 2. The alkaline treatment removes most of the surface substances resulting in fibers with relatively clean and even surface as seen from Figure 3. The single cells are pure cellulose and therefore have a clean and smooth surface as seen from Figure 4. The milk-

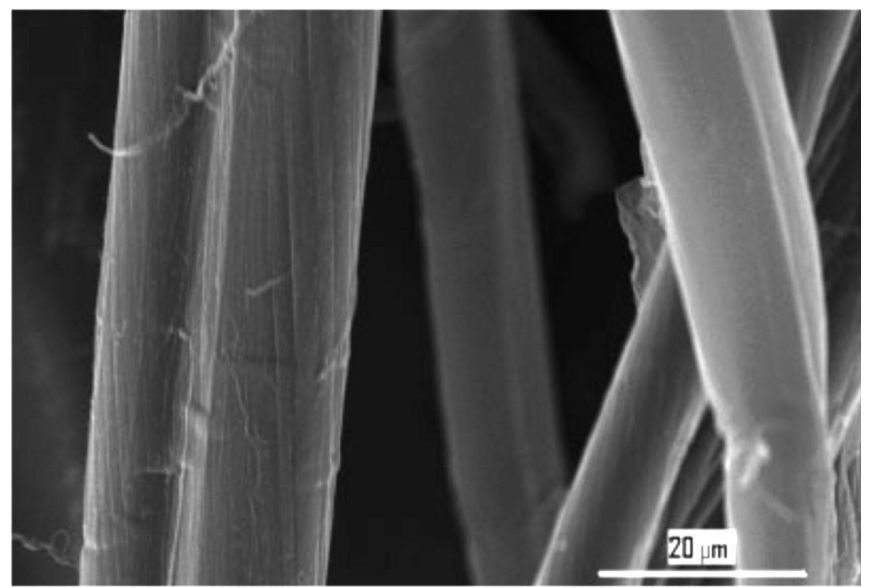

Figure 4. SEM image of the single cells in milkweed stem fibers. The single cells have a clean and smooth surface since most of the noncellulosic substances have been removed. 
Table 3. Fineness, length, mechanical properties, and moisture regain of milkweed stem fibers compared with milkweed floss, cotton, and linen.

\begin{tabular}{lcccc}
\hline $\begin{array}{l}\text { Fiber } \\
\text { properties }\end{array}$ & $\begin{array}{c}\text { Milkweed } \\
\text { stem fibers }\end{array}$ & $\begin{array}{c}\text { Milkweed } \\
\text { floss fibers }\end{array}$ & Cotton & Linen \\
\hline Denier & $104 \pm 17$ & - & $3-8$ & $1.7-17.8$ \\
Length, cm & $11.5 \pm 3.8$ & $2.9-3.0$ & $1.5-5.6$ & $20-140$ \\
Strength, g/den & $3.5 \pm 2.0$ & $2.3-2.7$ & $2.7-3.5$ & $4.6-6.1$ \\
$\begin{array}{l}\text { Elongation, \% } \\
\text { Modulus, g/den }\end{array}$ & $4.7 \pm 3.5$ & $1.2-2.0$ & $6.0-9.0$ & $1.6-3.3$ \\
$\begin{array}{l}\text { Work of rupture, g/den } \\
\text { Moisture regain, \% }\end{array}$ & 0.21 & - & $55-90$ & $195-205$ \\
& $9.6 \pm 0.1$ & 11.1 & $0.21-0.40$ & $0.09-0.26$ \\
\hline
\end{tabular}

Data for milkweed floss, cotton and linen are from references [6, 9, 30]. Errors indicate \pm one standard deviation.

weed stem fibers or single cells do not have the typical convolutions seen in cotton and some fibers obtained from agricultural byproducts [20].

\section{Fiber Properties}

Fibers obtained from milkweed stems have deniers of about 100, coarser than cotton and linen fibers. The presence of shorter and narrower width single cells should be the main reason for the coarser milkweed stem fibers compared to cotton and linen. As mentioned earlier, the milkweed floss and cotton are a single cell fiber which is a major reason for these fibers to have low deniers. Although it was possible to obtain finer milkweed stem fibers using stronger extraction conditions, the yield of the fibers decreases considerably at stronger extraction conditions. However, fibers with deniers similar to that of the milkweed stem fibers have been processed on the textile machines to produce yarns and composites [24, 25]. The milkweed stem fibers are longer than the floss fibers and cotton but in the range of length of the linen fibers. The milkweed stem fibers have adequate length for processing on both the short and long staple spinning machinery similar to cotton and linen, respectively [30].

Milkweed stem fibers have strength higher than milkweed floss, similar to that of cotton and lower than that of linen as seen from Table 3 and from the stress-strain curves in Figure 5. The presence of higher number of weak spots due to the shorter single cells and the low \% crystallinity of cellulose in the fibers are some of the reasons for the lower strength of the milkweed stem fibers when compared with linen. However, the strength of the milkweed stem fibers is similar or higher than that of other common bast fibers such as jute and the fibers obtained from various agricultural byproducts [14-20, 30]. Breaking elongation of the milkweed stem fibers is higher than that of milkweed floss and linen and most other bast fibers including those obtained from the byproducts of plants such as rice, wheat straw, and sorghum but lower than the elongation of the cotton fibers. The high elongation of the milkweed stem fibers indi-

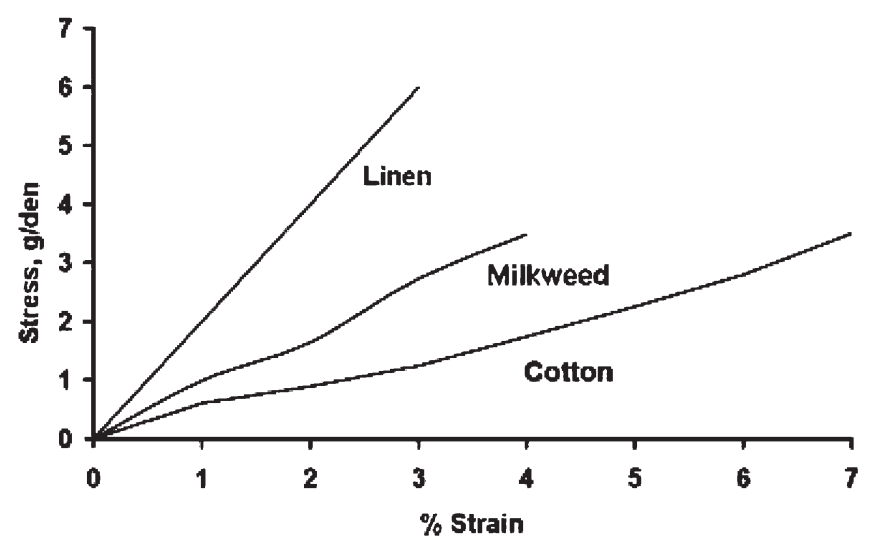

Figure 5. Stress-strain curves of milkweed stem fibers compared to cotton and linen.

cates that the fibers may have a higher microfibrillar angle than the common bast fibers. Modulus of the milkweed stem fibers is between that of cotton and linen fibers as seen from the stress-strain curves in Figure 5. The modulus of the fibers indicates that the fibers will be harsher than cotton but softer than linen. Although the milkweed stem fibers have lower strength, the higher elongation of the fibers gives the fibers durability similar to that of cotton as seen from the work or rupture data in Table 3 and stress-strain curves in Figure 5.

\section{Conclusions}

Stems of milkweed plants have been used to obtain natural cellulose fibers with better strength and elongation that the milkweed floss fibers. Milkweed stem fibers have high cellulose content but low \% crystallinity. The fibers have strength similar to cotton and elongation higher than that of linen fibers. The modulus and moisture regain of the milkweed stem fibers is between that of cotton and linen. Overall, the milkweed stem fibers have properties required for high value textile, composite, and other fi- brous applications. Utilizing the milkweed stems for high quality natural cellulose fibers will add value and make milkweed a more useful fiber plant.

\section{Acknowledgments}

We thank Natural Fiber Corporation, Ogallala, Nebraska, for supplying the milkweed stems.

\section{References}

I. E.A. Gaertner, Econ. Bot., 33, II9 (I979).

2. A. Nourbakhsh, A. Ashori, and M. Kouhpayehzadeh, J. Reinforced Plast. Comp., doi:I0.II77/0731684408091902.

3. H.D. Knudsen and R.D. Zeller, "The Milkweed Business," in New Crops, J. Janick and J.E. Simon, Eds., Wiley, New York, 422 (1993). 
4. P.C. Crews, S. Sievert, and L.T. Woeppel, Text. Res. J., 6I, 203 (I99I).

5. M.D. Witt and H.D. Knudsen, "The Milkweed Business," in New Crops, J. Janick and J.E. Simon, Eds., Wiley, New York, 428 (1993).

6. D.B. Shakyawar, R.S. Dagur, and N.P. Gupta, Indian J. Fibre Text. Res., 24, 264 (1999). v7. J.C. Sakthivel, S. Mukhopadhyay, and N.K. Palanisamy, J. Ind. Text., 35, 63 (2005).

8. J.F. Drean, J.J. Patry, G.F. Lombard, and M.Weltrowski, Text. Res. J., 63, 443 (1993).

9. G.L. Louis and B.A.K.Andrews, Text. Res.J., 57, 339 (1987).

10. R. Holser and H.K. Rogers, Fuel, 85, 2106 (2006).

II. T.A. Campbell and K.A. Grasse, Biomass, 9, 239 (1986).

12. R.A. Buchanan and J.A. Duke, "Botanical Crops," in CRC Handbook of Biosolar Resources, O. Zarborsky, Ed., CRC Press, Boca Raton, I57 (I98I).

13. L.V. Forman and D. Niemeyer, Pap.Trade J., I21, 29 (1945).

14. N. Reddy and Y.Yang, Green Chem., 7, 190 (2005).

15. N. Reddy and Y.Yang, Polymer, 46, 5494 (2005).

16. N. Reddy and Y.Yang, J.Agric. Food Chem., 54, 8077 (2006).

17. N. Reddy and Y.Yang, J.Agric. Food. Chem., 55, 8570 (2007).

18. N. Reddy and Y.Yang, Biotechnol. Bioeng., 97, I02I (2007).
19. N. Reddy, Bioresour. Technol., 99, 2449 (2008).

20. N. Reddy and Y.Yang, J. Agric. Food. Chem., 55, 5569 (2007).

2I. N. Reddy and Y.Yang, Trends Biotechnol., 23, 22 (2005).

22. I. Doraiswamy and P. Chellamani, Text. Prog., 24, I (1993).

23. B.J. Collier, J.R. Collier, P. Agarwal, and Y. Lo, Text. Res. J., 62, 7I4 (I992).

24. N. Reddy, D.D. Mcalister, and Y. Yang, Indian J. Fibre Text. Res., 3I, 537 (2006).

25. S. Huda and Y.Yang, Macromol. Mater. Eng., 293, 235 (2008).

26. S.E. Ruzin, Plant Microtechnique and Microscopy, Oxford University Press, New York, I I (1999).

27. K. Helrich, Official Methods of Analysis, Association of Official Analytical Chemists, Virginia, I 70 (1990).

28. Annual Book of ASTM Standards, American Society for Testing and Materials, West Conshohocken, PA, 4071998.

29. K.Ward, Text. Res. J., 20, 363 (1950).

30. S.K. Batra, "Other Long Vegetable Fibers," in Fiber Science and Technology, Vol. 4: Fibre Chemistry, M. Lewin and E.M. Pearce, Eds., Marcel Dekker, New York, 505 (1998).

3I. A.Thygesen, J. Oddershede, H. Lilholt, A.B. Thomsen, and K. Stahl, Cellulose, 12, 563 (2005). 